\title{
Inflation and Profitability of Commercial Banks in Rwanda: A Case Study of Bank of Kigali
}

\author{
Gilbert Batsinda $^{1} \&$ Jaya Shukla ${ }^{1}$ \\ ${ }^{1}$ Mount Kenya University, Kigali, Rwanda \\ Correspondence: Jaya Shukla, Mount Kenya University, Kigali, Rwanda. E-mail: jshukla@mku.ac.ke
}

Received: March 11, 2019

Accepted: August 15, 2019

Online Published: September 5, 2019

doi:10.5539/ijbm.v14n10p35

URL: https://doi.org/10.5539/ijbm.v14n10p35

\begin{abstract}
The study evaluates the impact of inflation on the profitability of commercial banks in Rwanda with specific focus on the Bank of Kigali. In Rwanda, the effect of inflation on the financial performance of commercial banks has not been adequately researched in relation to types of inflation. It is against this issue that the researcher wanted to carry out this research to find the relationship between inflation and profitability of commercial bank in Rwanda. The specific objectives of study were: to examine the trend of inflation in Rwanda; to examine the profitability of Bank of Kigali between 2011 and 2015; and to establish the relationship between inflation and profitability. To achieve objectives study used descriptive research design with population and sample size of 26 respondents. Correlation analysis is used to examine relationship between study variables. The study findings revealed that cost push inflation has positive high correlation to the Profitability of BK. Findings indicated that demand pull inflation and Monetary inflation has also positive high correlation profitability of Bank of Kigali. Finally it is concluded that the types of inflation affect commercial banks are cost push inflation, demand pull inflation and monetary inflation. Inflation has a significant role in enhancing commercial bank's profitability.
\end{abstract}

Keywords: inflation, profitability, cost push inflation, demand pull inflation

\section{Introduction}

Inflation is an increase in general prices over period of time. Inflation effects real economic activities of economy. According to research done by Levine in 2002 using data from four industrialized countries indicated differential impact of inflation on output growth in different countries studied. Boyd in 2001 through his research found a significant negative correlation between financial services of country and the rate of inflation. Another research by Senhadji in 2001 found direct correlation between inflation and decrease of deposits and loan given capacities of banks.

Monetary policy of Bank of Rwanda over years has become effective in controlling the effect of inflation in the formation of expectations and in banking prices. To this end, research tries to demonstrate the relationship between inflation and profitability of commercial bank in Rwanda. The study begins by recognizing that net profit of Bank of Kigali from 2011 up to 2012 were decreasing while between 2013 up to 2014, net profit were increasing. This means that net profits of Bank of Kigali during the period of study were fluctuating.

\subsection{Problem Statement}

Inflation effects economy both positively and negatively. Prolonged inflation may discourage investment and saving and may lead to shortages of goods if consumers begin hoarding them in expectation of high inflation in future. Positively it may relieve economy from economic recessions and could debt relief by reducing the real level of debt. The effect of inflation on the Rwandan economy has been experienced by various sectors in the economy including the banking sector. Huybens and Smith (2009) argued that rate of inflation at first have negative consequences on financial sector performance through credit market frictions before it affects economic growth. Azariadis and Smith (2006) emphasized on threshold level of inflation in the relationship between inflation and financial sector performance. Boyd in 2001, emphasized that negative impact of inflation on growth is associated with cash in advance models which consider money as complementary to capital.

In Rwanda commercial banks are playing an important role in growth of economy. The financial performance of commercial banks has impact on all sectors of economy. The effect of inflation on the financial performance of commercial banks has not been adequately researched especially in context of types of Inflation. The research 
aims at determining the relationship increase in the price levels on the real value of money and savings and investment behavior.

\subsection{Objectives of Study}

This study has both general and specific objectives:

\subsubsection{General Objective}

The general objective of this study was to evaluate the impact of inflation on commercial banks profitability with special specific focus on Bank of Kigali.

\subsubsection{Specific Objectives}

i. To examine the types of inflation affecting Bank of Kigali.

ii. To examine the profitability of Bank of Kigali between 2011 and 2017.

iii. To establish the relationship between inflation and profitability.

\subsection{Research Questions}

i. What are types of Inflation affecting Bank of Kigali?

ii. What was the profitability of BK between 2011 and 2017?

iii. What is the relationship between inflation and profitability?

\subsection{Conceptual Framework}

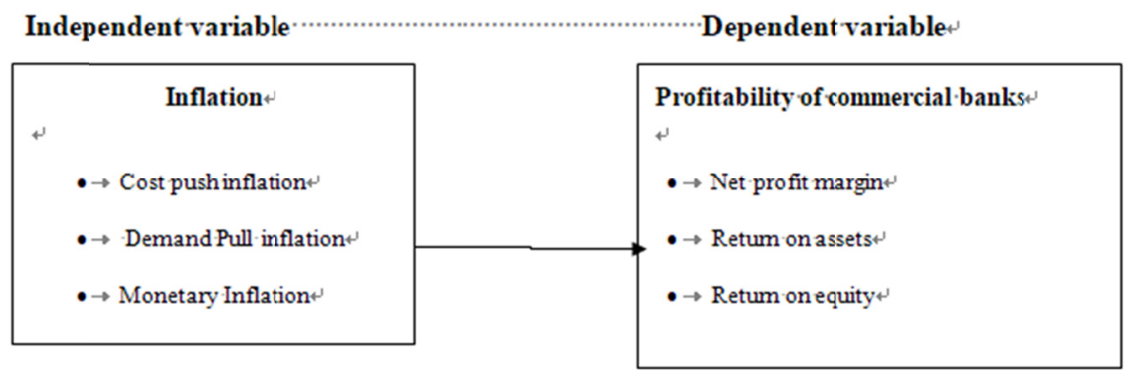

Figure 1. Conceptual framework

\section{Research Design}

Descriptive research design is used to describe the variables under study. Data analysis of the relationship between inflation and financial performance of commercial banks is done using correlation coefficient between variables under study.

\subsection{Target Population}

The target population for the study consisted of 26 employees from the credit department of Bank of Kigali, in Nyarugenge District, Kigali City.

Table 1. Showing the target population

\subsection{Sample Size}

\begin{tabular}{ll}
\hline Departments & Number of employees \\
\hline Credit department & 16 \\
Finance & 10 \\
Total population & 26 \\
\hline
\end{tabular}

Due to the smaller number of staff working in the credit department, all the 26 employees were contacted for interviews.

\subsubsection{Sampling Techniques}

In this study, the census sampling technique was used for selecting the 26 employees from the credit department of Bank of Kigali. 


\subsection{Data Collection Methods}

Data were collected using Questionnaire from respondents and documentary review.

\subsubsection{Data Collection Instruments}

The primary data were collected from the respondents using questionnaire and documentary review as secondary data.

\section{Research Results and Discussion}

\subsection{Presentation of the Findings}

\subsubsection{Trend of inflation in Rwanda}

In this section, the researcher wanted to find out the trend and the different types of inflation within in Bank of Kigali. The researcher identified 3 types of inflations within Bank of Kigali main branch such are cost- push inflation, demand pull inflation and monetary inflation.

\subsubsection{Cost- push inflation}

Respondent were asked to highlight whether cost- push inflation was among the types of inflation in the Bank of Kigali. Respondents' views are presented in Table 4.6 below. The views of the respondents on cost-push inflation discuss and interpret them in order to achieve the first specific objective of the study.

Table 2. Respondents' view on cost-push inflation

\begin{tabular}{|c|c|c|c|c|c|c|}
\hline Statements & SA (\%) & A (\%) & D (\%) & SD (\%) & Mean & Sd \\
\hline $\begin{array}{l}\text { BK raise its prices to maintain its profit margin } \\
\text { during 2011-2015 }\end{array}$ & 76.9 & 23.1 & 0 & 0 & 3.7692 & .42967 \\
\hline $\begin{array}{l}\text { BK has been characterized by labor costs form } \\
\text { the highest proportion of total costs during } \\
2011-2015\end{array}$ & 69.2 & 30.8 & 0 & 0 & 3.6923 & .47068 \\
\hline $\begin{array}{l}\text { Some raw materials most notably oil have } \\
\text { change the price during } 2011-2015 \text { which affect } \\
\text { your annual profit }\end{array}$ & 61.5 & 38.5 & 0 & 0 & 3.6154 & .49614 \\
\hline
\end{tabular}

Source: Researcher, 2018.

Table 2 reveals the perception of respondents on cost-push inflation. In assessing these variables, 3 statements (items) were considered and the findings are presented in Table 2. Table reveals that the employees of BK agreed that cost-push inflation raise its prices to maintain its profit margin during 2011-2015.

The first item was to know whether BK raises its prices to maintain its profit margin during 2011-2015. It was scored the mean of 3.7692 (strong), which mean that respondents agree that BK raise its prices to maintain its profit margin during 2011-2015.

In the second element researcher wanted to know whether BK had been characterized by labor costs from the highest proportion of total costs during 2011-2015. With a mean 3.6923 (strong), the respondents strongly agreed that BK had been characterized by labor costs from the highest proportion of total costs during 2011-2015.

In the third element, the researcher wanted to know whether some raw materials most notably oil had changed the price during 2011-2015 which affects annual profits. With a mean of 3.6154 (strong), the respondents strongly agreed that some raw materials most notably oil had changed the price during 2011-2015.

\subsubsection{Demand pull inflation}

Respondent were asked to highlight whether demand pull inflation is among the types of inflation in Bank of Kigali. 
Table 3. Respondents' views on demand pull inflation

\begin{tabular}{llllll}
\hline Statements SA(\%) & A (\%) & $\begin{array}{l}\text { D } \\
\text { (\%) }\end{array}$ & SD (\%) & Mean & Sd \\
\hline BK was characterized by higher & 65.4 & 34.6 & 0 & 0 & 3.6538 \\
$\begin{array}{l}\text { investments during 2011-2015 } \\
\text { BK was characterized by high aggregate } \\
\text { demand results in higher output but no } 61.5\end{array}$ & 38.5 & 0 & 0 & 3.6154 \\
increase in the price level during 2011-2015
\end{tabular}

Source: Researcher, 2018.

Table 3 reveals that the employees of BK agreed that demand pull inflation through the 2 statements. BK was characterized by high aggregate demand results in higher output but no increase in the price level during 2011-2015.

The first item was to know whether BK was characterized by higher investments during 2011-2015. It was scored with the mean of 3.6538 (high), meaning that respondents agreed that BK was characterized by higher investments during 2011-2015.

In the second element, the researcher wanted to know whether BK was characterized by high aggregate demand results in higher output but no increase in the price level during 2011-2015. With a mean of 3.6154 (strong), the respondents strongly agreed that BK was characterized by high aggregate demand results in higher output but no increase in the price level during 2011-2015.

\subsubsection{Monetary inflation}

Respondent were asked to highlight whether monetary inflation was among the types of inflation in Bank of Kigali. Respondents' views are presented in the tables. The views of respondents on monetary inflation.

Table 4. Respondents' views on monetary inflation

\begin{tabular}{llllll}
\hline Statements & SA (\%) & A (\%) & $\begin{array}{l}\text { D } \\
(\%)\end{array}$ & SD (\%) & Mean \\
\hline $\begin{array}{l}\text { Money supply increasing faster through } \\
\text { output in BK ltd during 2011-2015 }\end{array}$ & 73.1 & 26.9 & 0 & 0 & 3.7308 \\
$\begin{array}{l}\text { BK Spend more which lead on increasing in } \\
\text { price during 2011-2015 }\end{array}$ & 65.4 & 34.6 & 0 & 0 & 3.6538 \\
\hline
\end{tabular}

Source: Researcher, 2018.

Table 4 shows that the perception of respondents on monetary inflation. In assessing this variable, 2 statements (Items) were considered and the findings are presented in Table 4 which shows that the employees of BK agreed that monetary inflation through the 2 statements.

\subsubsection{Profitability of Bank of Kigali between 2011 and 2017}

In this section, the researcher analysed the financial statements of Bank of Kigali, using financial ratio analysis. The analysis revealed the strength and weaknesses of the company and its financial position. The following section displays the financial ratios including profitability ratio, the company in the period of study (2011-2017). The following section displays the financial ratios of the company in the stated period. 
Table 5. Profitability ratio analysis

\begin{tabular}{|c|c|c|c|c|c|c|c|}
\hline Items & 2011 & 2012 & 2013 & 2014 & 2015 & 2016 & 2017 \\
\hline $\begin{array}{l}\text { NET PROFIT } \\
\text { (in Thousands Rwf) }\end{array}$ & $8,688,765$ & $11,781,336$ & $14,830,235$ & $18,316,825$ & $20,484,058$ & $20,730,879$ & $23,246,922$ \\
\hline $\begin{array}{l}\text { TOTAL EQUITY } \\
\text { ((in Thousands Rwf) }\end{array}$ & $63,107,293$ & $61,584,332$ & $70,763,684$ & $89,547,734$ & $99,245,545$ & $108,302,384$ & $122,471,529$ \\
\hline $\begin{array}{l}\text { Total asset } \\
\text { (in Thousands Rwf) }\end{array}$ & $322,794,214$ & $287,899,874$ & $422,360,073$ & $482,607,964$ & $561,226,400$ & $639,117,735$ & $727,160,327$ \\
\hline $\begin{array}{l}\text { Revenue } \\
\text { (in Thousands Rwf) }\end{array}$ & $32,069,789$ & $22,671,124$ & $45,210,752$ & $51,909,827$ & $59,966,855$ & $93,463,520$ & $110,778,158$ \\
\hline ROE & 0.13 & 0.19 & 0.2 & 0.2 & 0.2 & 0.19 & 0.19 \\
\hline ROA & 0.02 & 0.04 & 0.035 & 0.037 & 0.036 & 0.03 & 0.03 \\
\hline NPM & 0.27 & 0.51 & 0.32 & 0.35 & 0.34 & 0.22 & 0.21 \\
\hline
\end{tabular}

Source: Researcher's Interpretation of Bank of Kigali Annual Reports (2011-2017).

According to Table 5, BK has experienced increasing return on equity which is positive indicating that the company was profitable and generate enough profits to meets its shareholders expectations in the years of 2011 up to 2015.

In 2011, each 1Rwf invested in total assets generated $0.27 \mathrm{Rwf}$ as net profit. This demonstrates that the amount of capital invested in assets by BK generated profits which are used to covers its operating costs. This means that the inflation lead to a higher profit of this company as capital invested in assets by BK generated profits which are used to covers its operating costs. Furthermore, in 2013 and 2015 bank recognized the decreasing of NPM, this is because of some clients failure to pay back loan granted by BK. This provides the decreasing of profit from the years of 2012 up to 2013 and 2014 up to 2015.

Inflation raises interest rates. Higher interest rates provide more opportunity for banks to build in a profit margin. At the same time, the cost of funds also goes up - which can reduce profits. The trick is to keep those two competing forces in balance. Also, Interest Rates tend to rise with inflation but the banks' costs of funds (what they pay depositors) lag, providing spread. The profitability of Bank of Kigali during the period 2011-2015 was as follows:

Table 6. Bank of Kigali net profits

\begin{tabular}{llll}
\hline Year & Net profit & Variance & Percentage \\
\hline 2010 & $6,178,582,000$ & 0 & 0 \\
2011 & $8,688,765,000$ & 2.510 .183 .000 & $28.8 \%$ \\
2012 & $11,781,336,000$ & 3.092 .571 .000 & $26.2 \%$ \\
2013 & $14,830,335,000$ & 3.048 .999 .000 & $20.5 \%$ \\
2014 & $18,316,825,000$ & 3.486 .490 .000 & $19.0 \%$ \\
2015 & $20,484,058,000$ & 2.167 .233 .000 & $10.5 \%$ \\
2016 & $20,730,879,000$ & $246,821,000$ & $1.2 \%$ \\
2017 & $23,246,922,000$ & $2,516,043,000$ & $12 \%$ \\
\hline
\end{tabular}

Source: Bank of Kigali Annual Reports (2011-2017).

In 2012 BK profits grew to RwF 11.8 billion accounting for over $50 \%$ of the total banking sector profits. The increase in profitability was mainly driven by a $43 \%$ growth in net interest income to RwF 23.7 billion. Non-Interest income grew by $14.1 \%$ to reach RwF 14.7 billion driven by an increase in fees and commissions income which grew by an impressive $54.4 \%$ to reach RwF 6.7 billion. Net Provisions for non-performing loans decreased by $19.7 \%$ to RwF 3.6 billion driven by high recoveries during the year.

BK's balance sheet rose by $12.1 \%$ in an environment of global economic challenges clearly demonstrating the resilience of the Bank. Total assets were RwF 322.8 billion with growth mainly supported by higher loans and advances. The loan book grew by $50.3 \%$ to RwF 185.1 billion, mainly driven by consumer lending which now accounts for $32 \%$ of total loans. On the liability side, the growth in customer deposits was $15.1 \%$ reaching RwF 208.4 billion driven by gains from the branch and alternative channels expansion strategy. 
Table 7. Respondents' views on the profitability of BK

\begin{tabular}{|c|c|c|c|c|}
\hline Statements & Mean & Comment & SD & Comment \\
\hline $\begin{array}{l}\text { Profitability of BK was highly appreciated during } 2011 \\
\text { up to } 2015\end{array}$ & 3.6154 & High & .49614 & Homogeneity \\
\hline $\begin{array}{l}\text { Operating income of BK was highly appreciated during } \\
2011 \text { up to } 2015\end{array}$ & 3.6923 & High & .47068 & Homogeneity \\
\hline $\begin{array}{l}\text { Operating expenses of BK was highly appreciated during } \\
2011 \text { up to } 2015\end{array}$ & 3.8462 & High & .36795 & Homogeneity \\
\hline $\begin{array}{l}\text { Net income of BK was highly appreciated during } 2011 \text { up } \\
\text { to } 2015\end{array}$ & 3.6538 & High & .48516 & Homogeneity \\
\hline $\begin{array}{l}\text { Gross Profit Margin of BK was highly appreciated } \\
\text { during } 2011 \text { up to } 2015\end{array}$ & 3.8462 & High & .36795 & Homogeneity \\
\hline $\begin{array}{l}\text { Net Profit Margin of BK was highly appreciated during } \\
2011 \text { up to } 2015\end{array}$ & 3.6923 & High & .47068 & Homogeneity \\
\hline
\end{tabular}

Source: Researcher, 2018.

Table 7 shows the perceptions of respondents on the profitability of Bank of Kigali. In assessing these variables, 6 statements (Items) were considered and the findings are presented in the Table 7. The first item was to know whether profitability of BK was highly appreciated during 2011 up to 2015. It was scored the mean of 3.6154 (strong), which mean that respondents agree that profitability of BK was highly appreciated during 2011 up to 2015.

In the second element, the researcher wanted to know whether operating income of BK was highly appreciated during 2011 up to 2015. With a mean 3.6923 (strong), the respondents strongly agreed that operating income of BK was highly appreciated during 2011 up to 2015 .

In the third element researcher would like to know whether operating expenses of BK was highly appreciated during 2011 up to 2015. With a mean 3.8462 (strong), the respondents strongly agreed that operating expenses of BK was highly appreciated during 2011 up to 2015 .

In the fourth element researcher would like to know whether Net income of BK was highly appreciated during 2011 up to 2015. With a mean 3.6538 (strong), the respondents strongly agreed that Net income of BK was highly appreciated during 2011 up to 2015 .

In the fifth element researcher would like to know whether Gross Profit Margin of BK was highly appreciated during 2011 up to 2015. With a mean 3.8462 (strong), the respondents strongly agreed that Gross Profit Margin of BK was highly appreciated during 2011 up to 2015.

In the sixth element researcher would like to know whether Net Profit Margin of BK was highly appreciated during 2011 up to 2015. With a mean 3.6923 (strong), the respondents strongly agreed that Net Profit Margin of BK was highly appreciated during 2011 up to 2015.

Generally, the items assessing the profitability of Bank of Kigali showed an overall mean of 3.724367 (strong). The annual inflation rate in Rwanda decreased to 0.6 percent year-on-year in July of 2018 from 1.4 percent in June. Prices slowed for housing and utilities (11.2 percent compared to 12 percent in June); clothing and footwear (2.1 percent compared to 2.8 percent) and furnishings and household equipment (1.3 percent compared to 2.4 percent). Additionally, cost of food and non-alcoholic beverages dropped further ( -5.7 percent compared to -3.7 percent). On the other hand, prices increased faster for transport (10.2 percent compared to 9 percent); alcoholic beverages and tobacco (1.6 percent compared to 0.2 percent); restaurants and hotels $(0.2$ percent compared to 0.1 percent) and miscellaneous goods and services ( 2.2 percent compared to 0.5 percent). On a monthly basis, consumer prices fell 0.8 percent, after a 1.4 percent decline in the previous month. Inflation Rate in Rwanda averaged 6.08 percent from 1997 until 2018, reaching an all-time high of 28.10 percent in February of 1998 and a record low of - 15.80 percent in February of 1999.

\subsubsection{Relationship between Inflation and Profitability}

This section concentrates on the relationship between the two variables: demand pull inflation and profitability. 
Table 8. Correlation between Cost Push Inflation and profitability of BK

\begin{tabular}{|c|c|c|c|c|}
\hline & & & Consumer price index & Profitability of BK \\
\hline \multirow[t]{5}{*}{ Spearman's rho } & Consumer price index & Correlation & 1 & $.876^{* *}$ \\
\hline & & Coefficient & & \\
\hline & & $\mathrm{N}$ & 26 & 26 \\
\hline & Profitability of BK Ltd & Correlation & $.876^{* *}$ & 1 \\
\hline & & $\mathrm{N}$ & 26 & 26 \\
\hline
\end{tabular}

**. Correlation is significant at the 0.01 level (2-tailed).

Source: Researcher, 2018.

Table 8 indicates that Cost Push inflation has positive high correlation to the profitability of Bank of Kigali which is equal to $.876^{* *}$ with the sig. of .000 which is less than 0.01 indicating significant correlation between variables of study.

Table 9. Correlation between Demand Pull Inflation and profitability of BK

\begin{tabular}{|c|c|c|c|c|}
\hline & & & Product price index & Profitability of BK \\
\hline \multirow[t]{8}{*}{ Spearman's rho } & Product price index & Correlation & 1 & $.870^{* *}$ \\
\hline & & Coefficient & & \\
\hline & & Sig. (2-tailed) & . & .000 \\
\hline & & $\mathrm{N}$ & 26 & 26 \\
\hline & Profitability of BK Ltd & Correlation & $.870^{* *}$ & 1 \\
\hline & & Coefficient & & \\
\hline & & Sig. (2-tailed) & .000 & . \\
\hline & & $\mathrm{N}$ & 26 & 26 \\
\hline
\end{tabular}

**. Correlation is significant at the 0.01 level (2-tailed)

Source: Researcher, 2018.

Table 9 indicates that Demand Pull Inflation has positive high correlation to the profitability of Bank of Kigali which is equal to $.870^{* *}$ with the sig. of .000 which is less than 0.01 implying significant correlation between variables.

\subsection{Relationship between Monetary Inflation and Profitability of BK}

This section concentrates on the relationship between monetary inflation and profitability (ROE, ROA and NPM) of Bank of Kigali Ltd. All responses related to the questions of monetary inflation were summarized to generate a representative independent variable while all responses related to the profitability (ROE, ROA and NPM) of Bank of Kigali Ltd were totaled to give the dependent variable.

Table 10. Correlation between monetary inflation and profitability of BK

\begin{tabular}{lllll}
\hline & & Monetary inflation & Profitability of BK \\
\hline Spearman's & Monetary & Correlation & 1 & $.795^{* *}$ \\
rho & inflation & Coefficient & & .000 \\
& & Sig. (2-tailed) &. & 26 \\
& $\mathrm{~N}$ & 26 & 1 \\
& Profitability of & Correlation & $.795^{* *}$ &. \\
& BK Ltd & Coefficient & & 26 \\
\hline
\end{tabular}

**. Correlation is significant at the 0.01 level (2-tailed).

Source: Researcher, 2018. 
Table 10 shows that monetary inflation has high correlation to the profitability of Bank of Kigali which is equal to $.795^{* *}$ with the sig. of .000 which is less than 0.01 .

In conclusion, sample size $\mathrm{N}$ is 26 and the significant level is 0.01 , after comparing types of inflation with its sub variable (cost push inflation, demand pull inflation and monetary inflation) and profitability (ROE, ROA and NPM) of commercial bank results indicated that inflation has a positive high correlation to the commercial bank profitability which is $0.8296^{* *}$ and the sig is 0.000 less than 0.01 . This means that inflation have a significant role in enhancing commercial bank profitability.

\section{Conclusion and Recommendations}

\subsection{Conclusion}

The types of inflation affect commercial banks such Bank of Kigali are Cost Push, Demand Pull and monetary inflation. The profitability of Bank of Kigali was highly appreciated in from 2011 up to 2015. After comparing inflation with its sub variable (Consumer Price Index (CPI), Producer Price Index (PPI) and monetary inflation) and profitability (ROE, ROA and NPM) of commercial bank results indicated that inflation has a positive high correlation to the commercial bank profitability which is $0.8296^{* *}$ with the sig of 0.000 which is less than 0.01 and when sig. is less than significant level, implying that inflation has a significant role in enhancing commercial bank's profitability. Inflation rate is conducted on regular basis increase commercial bank profit (ROE, ROA and NPM). The results are in line with Tan \& Floros (2012) who found through their study in China that there is a positive relationship between bank profitability, cost efficiency, banking sector development, stock market development and inflation.

\subsection{Recommendations}

The study shows that there is positive Correlation between Inflation and Profitability of Commercial Banks in Rwanda but this profitability cannot be sustainable in pace of banking competition that there is need that Bank of Kigali should try to control inflation and generate profits through innovation and high Quality Service.

\section{References}

Amin, M. E. (2005). Social Science Research: Conception, Methodology and Analysis. Kampala: Makerere University Press, Kampala.

Asari, M., \& Jusoff, K. (2011). An Analysis of Non-Performing Loan, Interest Rate and Inflation Rate using Stata Software. World Applied Science Journal, 12(1), 41-48. https://doi.org/10.1007/BF00141041

Azariadis, C., \& Smith, B. D. (1996). Private Information, Money, and Growth: Indeterminacy, Fluctuations, and the Mundell-Tobin Effect. Journal of Economic Growth, Springer, 1(3), 309-332.

Beck, R., Jakubik, P., \& Piloiu, A. (2013). Non-Performing Loans what matters in addition to the Economic Cycle? ECB Working Paper Series NO 1515. European Central Bank.

BNR. (2013). BNR Annual report 2012. Kigali: BNR. Retrieved from http://Annual_Financial_Stability_Report_July_2012_-_June_2013.pdf

BNR. (2015). BNR Annual report 2014. Kigali. Retrieved from http://BNR_ANNUAL_REPORT_2014.pdf

Boyd, H. J., Ross, L., \& Bruce, D. S. (2000). The Impact of Inflation on Financial Sector Performance. Carlson School of Management, University of Minnesota, Minneapolis, MN 55455, USA.

Boyd, J., \& Champ, B. (2004). Inflation and Financial Market Performance: What Have We Learned in the Last Ten Years? University of Minnesota. Carlson School of Management and Federal Reserve Bank of Cleveland. https://doi.org/10.26509/frbc-wp-200317

Chowdhury, K. E. (2012). Impact of Inflation on Bank Lending Rates in Bangladesh. Journal of Politics \& Governance, 19(1), 5-13.

Evans, M., \& Karen, L. (2005). Do Expected Shifts in Inflation affect estimates of the Long Run Fisher Relation? Journal of Finance, 50(1), 225-53. https://doi.org/10.1111/j.1540-6261.1995.tb05172.x

Goddard, J., Molyneux, P., \& Wilson, J. O. S. (2004). Dynamics of Growth and Profitability in Banking. Journal of Money, Credit \& Banking, 36(6), 10-69. https://doi.org/10.1353/mcb.2005.0015

Guru, B., Staunton, J., \& Balashanmugam, B. (2002). Determinants of Commercial Bank Profitability in Malaysia. Paper presented at the 12th Annual Australian Finance and Banking Conference, 16-17 December, Sydney, Australian.

Huybens, E., \& Smith, B. (2009). Inflation, Financial Markets, and Long-Run Real Activity. Journal of 
Monetary Economics, 43(1), 283-315. https://doi.org/10.1016/S0304-3932(98)00060-9

\section{Copyrights}

Copyright for this article is retained by the author(s), with first publication rights granted to the journal.

This is an open-access article distributed under the terms and conditions of the Creative Commons Attribution license (http://creativecommons.org/licenses/by/4.0/). 